\title{
PENERAPAN METODE SIMPLE ADDITIVE WEIGHT (SAW) DALAM SISTEM PENDUKUNG KEPUTUSAN PROMOSI KENAIKAN JABATAN
}

\author{
Frieyadie \\ Program Studi Manajemen Informatika \\ AMIK BSI Jakarta \\ Jl. RS. Fatmawati No. 24 Pondok Labu, Jakarta Selatan \\ frieyadie@bsi.ac.id
}

\begin{abstract}
HR management of a company greatly affect many aspects of determining the success of the work of the company. One very important process in the Human Resources Department (HRD) a company or entity that is the promotion of a promotion. In general, the promotion was given on the recommendation boss or work unit each based on the old work, the performance assessment and assessment of the behavior of an employee in performing their duties. For that it is necessary appraisal data processing employees who can help facilitate a supervisor and the human resources department to take a decision relating to the promotion of an employee promotions. Currently the company employee appraisal data processing is still performed with computerized excel, so the greater the risk of inputting errors given the number of employees very much and and it takes a relatively long time. It is also still often confusing information regarding the movement of formation of employees. The method used in determining promotion This promotion is Simple Additive Weight (SAW). Where this method is a weighted counting method or methods that provide certain criteria are weighted so that each value of the sum of the weights of the obtained results will be the final decision. Judging from the managerial aspects of the assessment can be developed with other criteria in accordance with the company's needs. Calculations using Simple Additive Weight, with reference to the criteria of employment, performance evaluation, and assessment of employee behavior, then elect an employee who will get promotion.
\end{abstract}

Intisari - Manajemen SDM dari perusahaan sangat mempengaruhi banyak aspek penentu keberhasilan kerja perusahaan. Salah satu proses yang sangat penting dalam Departemen Sumber Daya Manusia (SDM) suatu perusahaan atau badan yang promosi promosi. Secara umum, promosi itu diberikan pada bos rekomendasi atau unit kerja masing-masing berdasarkan pekerjaan lama, penilaian kinerja dan penilaian perilaku karyawan dalam melaksanakan tugasnya. Untuk itu maka diperlukan penilaian karyawan pengolahan data yang dapat membantu memfasilitasi pengawas dan departemen sumber daya manusia untuk mengambil keputusan yang berkaitan dengan promosi dari promosi karyawan. Saat ini pengolahan data penilaian karyawan perusahaan masih dilakukan dengan komputerisasi excel, sehingga semakin besar risiko kesalahan memasukkan mengingat jumlah karyawan sangat banyak dan dan dibutuhkan waktu yang relatif lama. Hal ini juga masih sering membingungkan informasi mengenai pergerakan pembentukan karyawan. Metode yang digunakan dalam menentukan promosi Promosi ini Simple Additive Weight (SAW). Di mana metode ini adalah metode penghitungan tertimbang atau metode yang menyediakan kriteria tertentu yang berbobot sehingga setiap nilai jumlah dari bobot dari hasil yang diperoleh akan menjadi keputusan akhir. Dilihat dari aspek manajerial penilaian dapat dikembangkan dengan kriteria lain sesuai dengan kebutuhan perusahaan. Perhitungan menggunakan Simple Additive Berat, dengan mengacu pada kriteria pekerjaan, evaluasi kinerja, dan penilaian perilaku karyawan, kemudian memilih seorang karyawan yang akan mendapatkan promosi.

Kata Kunci: HRD, Job promotion, Simple Additive Weight

\section{PENDAHULUAN}

SDM dari suatu perusahaan sangat mempengaruhi banyak aspek penentu keberhasilan kerja dari perusahaan tersebut. Salah satu proses yang sangat penting dalam Human Resources Departement (HRD) sebuah perusahaan atau badan usaha yaitu proses promosi kenaikan jabatan. Menurut (Asnawati dan Kanedi, 2012) Persaingan para karyawan yang semakin ketat membuat sebuah keputusan kenaikan pangkat semakin sulit untuk diputuskan, terutama jika ada beberapa karyawan yang memiiki kemampuan yang tidak jauh berbeda. Pengambilan keputusan yang tidak adil dapat menimbulkan dampak buruk bagi suatu perusahaan. Hal ini dapat menurunkan 
tingkat kinerja para karyawan pada perusahaan tersebut. Untuk itu diperlukan pengambilan keputusan yang tepat dan cermat untuk menentukan kenaikan pangkat para karyawan. Pada umumnya promosi jabatan diberikan atas rekomendasi atasan atau unit kerja masingmasing berdasarkan lama bekerja, penilaian kinerja dan penilaian perilaku seorang karyawan dalam menjalankan tugasnya. Untuk itu maka diperlukan pengolahan data penilaian karyawan yang dapat membantu mempermudah seorang atasan dan bagian HRD untuk mengambil sebuah keputusan yang berkaitan dengan promosi kenaikan jabatan seorang karyawan. Saat ini pengolahan data penilaian karyawan diperusahaan tersebut masih dilakukan dengan komputerisasi excel, sehingga besar kemungkinan terjadinya kesalahan penginputan mengingat jumlah karyawan yang sangat banyak dan dan dibutuhkan waktu yang relatif lama. Selain itu juga masih sering terjadi informasi yang simpang siur mengenai pergerakan formasi karyawan. Metode yang digunakan dalam menentukan promosi kenaikan jabatan ini adalah Simple Additive Weight (SAW). Dimana metode ini merupakan metode pembilangan terbobot atau metode yang memberikan kriteria-kriteria tertentu yang memiliki bobot nilai masing masing sehingga dari hasil penjumlahan bobot tersebut akan diperoleh hasil yang menjadi keputusan akhirnya. Penyelesaian masalah menggunakan metode Simple Additive Weighting (SAW) untuk menjabarkan bobot-bobot yang sesuai dengan kriteria yang pantas kenaikan Jabatan menggunakan cara manual sehingga membutuhkan banyak waktu untuk menentukan dengan banyak bobot yang dibutuhkan dalam penentuan karyawan yang berhak Kenaikan Jabatan sesuai dengan kemampuan dan bidang masing-masing karyawan (Silalahi, 2013). Adapun tujuan penulisan ilmiah ini, adalah: 1) Sebagai salah satu alternatif untuk membantu seorang pimpinan dalam menentukan keputusan terkait promosi kenaikan jabatan seorang karyawan untuk posisi tertentu sesuai dengan syarat dan kebutuhan perusahaan. 2) Melakukan penilaian dari setiap kriteria untuk pemilihan karyawan. 3) Merancang suatu Sistem Pendukung Keputusan untuk Kenaikan Jabatan untuk mendapatkan karyawan yang memenuhi syarat dan kriteria jabatan tertentu dengan cepat dan sesuai dengan kebutuhan perusahaan.

\section{BAHAN DAN METODE}

\section{Sistem Pendukung Keputusan}

Menurut (Kusrini, 2007) "Sistem merupakan kumpulan elemen yang saling berkaitan yang bertanggung jawab memproses masukan (input) sehingga menghasilkan keluaran (output)."

Menurut Davis dalam Hartono (2013:120) mengemukakan bahwa Terdapat dua model pengambilan keputusan, yaitu model sistem tertutup dan model sistem terbuka.

a. Model Sistem Tertutup

Model sistem tertutup dilandasi asumsi bahwa keputusan dapat diambil tanpa campur tangan dari lingkungan (luar) sistem, karena sistem pengambilan keputusan tidak dipengaruhi oleh lingkungan. Dalam hal ini sistem pengambilan keputusan dianggap:

1) Mengetahui semua alternatif tindakan untuk menanggapi permasalahan dengan segala konsekuensinya.

2) Memiliki metode untuk menyusun alternatif-alternatif sesuai prioritasnya.

3) Dapat memilih/menetapkan alternatif yang paling menguntungkan, misalnya dari segi laba, manfaat, dan lain-lain.

b. Model Sistem Terbuka

Model sistem terbuka dilandasi asumsi bahwa sistem pengambilan keputusan dan lingkungan memiliki hubungan saling pengaruh. Keputusan yang diambil akan berdampak terhadap lingkungan dan sebaliknya lingkungan juga berpengaruh terhadap sistem pengambilan keputusan. Dalam hal ini sistem pengambilan keputusan dianggap:

1) Hanya mengetahui sebagian saja dari alternatif-alternatif untuk menangani permasalahan dengan segala konsekuensinya.

2) Hanya dapat menyajikan sejumlah alternatif yang baik untuk menangani permasalahan, tetapi tidak dapat memilih/menetapkan alternatif yang paling menguntungkan.

3) Sekadar mempersilakan pemilihan alternatif terbaik untuk dilakukan oleh pijak diluar sisten sesuai dengan aspirasinya.

\section{Metode Simple Additive Weight (SAW),}

Menurut Fishburn dan MacCrimmon dalam (Munthe, 2013) mengemukakan bahwa Metode Simple Additive Weight (SAW), sering juga dikenal dengan istilah metode penjumlahan terbobot. Konsep dasar metode Simple Additive Weight (SAW) adalah mencari penjumlahan terbobot dari rating kinerja pada setiap alternatif pada semua atribut.

Menurut (Asnawati dan Kanedi, 2012) "Kriteria penilaian dapat ditentukan sendiri sesuai dengan kebutuhan perusahaan." 
terbesar yang dipilih sebagai alternatis terbaik $\left(\mathrm{A}_{\mathrm{i}}\right)$ sebagi solusi.

\section{HASIL DAN PEMBAHASAN}

Berikut penjabaran hasil penelitian berisi Dimana :

$\mathrm{R}_{\mathrm{ij}} \quad=$ Rating kinerja ternormalisasi

$\operatorname{Max}_{i j}=$ Nilai maksimum dari setiap baris dan kolom

$\operatorname{Min}_{\mathrm{ij}}=$ Nilai minimum dari setiap baris dan kolom

Xij $=$ Baris dan kolom dari matriks

Dengan $\mathrm{R}_{\mathrm{ij}}$ adalah rating kinerja ternormalisasi dari alternatif Ai pada atribut $\mathrm{Cj} ; \mathrm{i}=1,2, \ldots \mathrm{m}$ dan $\mathrm{j}$ $=1,2, \ldots, \mathrm{n}$.

$V_{i}=\sum_{j=1}^{n} W_{j} R_{i j}$

Nilai Vi yang lebih besar mengindikasikan bahwa alternatif Ai lebih terpilih.

Dimana :

$\mathrm{V}_{\mathrm{i}} \quad=$ Nilai akhir dari alternatif

$\mathrm{W}_{\mathrm{i}} \quad$ = Bobot yang telah ditentukan

$\mathrm{R}_{\mathrm{ij}} \quad=$ Normalisasi matriks

Nilai yang lebih besar mengindikasikan bahwa alternatif lebih terpilih. Menurut (Nofriansyah, 2014) Metode Simple Additive Weighting (SAW) disarankan untuk menyelesaikan masalah penyeleksian dalam sistem pengambilan keputusan multi proses. Metode Simple Additive Weight (SAW) merupakan metode yang banyak digunakan dalam pengambilan keputusan yang memiliki banyak atribut.

Menurut Fishburn dan MacCrimmon dalam (Munthe, 2013) Ada beberapa langkah dalam penyelesaian metode Simple Additive Weight (SAW) adalah sebagai berikut:

1. Menentukan kriteria-kriteria yang dijadikan acuan dalam pendukung keputusan yaitu $\mathrm{Ci}$.

2. Menentukan rating kecocokan setiap alternatif pada setiap kriteria.

3. Membuat matriks keputusan berdasarkan kriteria $\left(\mathrm{C}_{\mathrm{i}}\right)$.

4. Kemudian melakukan normalisasi matriks berdasarkan persamaan yang disesuaikan dengan jenis atribut (atribut keuntungan maupun atribut biaya) sehingga diperoleh matriks ternormalisasi R.

5. Hasil akhir diperoleh dari proses perangkingan yaitu penjumlahan dari perkalian matriks ternormalisasi $\mathrm{R}$ dengan vector bobot sehingga diperoleh nilai paparan hasil analisis keputusan promosi menggunakan metode Simple Additive Weight (SAW)

\section{Struktur Simple Additive Weight}

Berikut struktur Simple Additive Weight keputusan yang akan digunakan dalam penelitian ini:

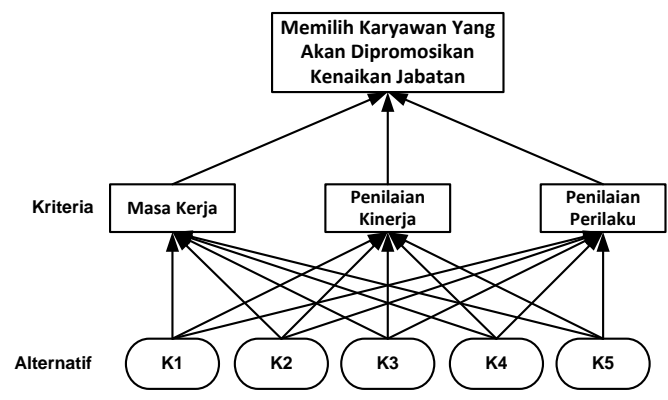

Sumber: Hasil olahan (2016)

Gambar 1. Struktur Hirarki Alternatif Penentuan Promosi Kenaikan Jabatan Karyawan

\section{Penentuan Kriteria Metode Simple Additive Weight}

Untuk melakukan pengambilan keputusan ini terdapat obyek yang akan dibahas atau goal, kriteria dan alternatif. Berikut adalah kriteriakriteria yang dibutuhkan untuk mengukur dan menilai siapa yang akan terseleksi untuk mendapatkan promosi kenaikan jabatan, antara lain:

\section{a. Masa Kerja}

Indikator yang digunakan dalam penentuan promosi kenaikan jabatan berdasarkan kriteria masa kerja dimana dinilai atau dilihat dari seberapa lama seorang karyawan sudah bekerja dalam perusahaan.

Tabel 1. Kriteria Masa Kerja

\begin{tabular}{clc}
\hline Kriteria & \multicolumn{1}{c}{ Range } & Bobot \\
\hline Masa Kerja & 2 Tahun & 0,2 \\
\cline { 2 - 3 } & 3 Tahun & 0,4 \\
\cline { 2 - 3 } & 4 Tahun & 0,6 \\
\cline { 2 - 3 } & 5 Tahun & 0,8 \\
\cline { 2 - 3 } & $>5$ Tahun & 1 \\
\hline
\end{tabular}

Sumber : Data olahan (2015) 


\section{b. Penilaian Kinerja}

Indikator yang digunakan dalam menentukan promosi kenaikan jabatan berdasarkan penilaian kinerja atau pencapaian target karyawan dalam menyelesaikan pekerjaannya.

Tabel 2. Penilaian Kinerja

\begin{tabular}{|c|c|c|c|}
\hline Kriteria & Range & $\begin{array}{l}\text { Skala } \\
\text { Nilai }\end{array}$ & Bobot \\
\hline \multirow{6}{*}{$\begin{array}{l}\text { Penilaian } \\
\text { Pencapaian } \\
\text { Target } \\
\text { Kinerja } \\
\text { Karyawan }\end{array}$} & $\begin{array}{l}<60 \% \quad \text { (Tidak } \\
\text { Baik) }\end{array}$ & 1 & 0,2 \\
\hline & $\begin{array}{l}60 \%-<75 \% \\
\text { (Perlu } \\
\text { Perbaikan) }\end{array}$ & 2 & 0,3 \\
\hline & $\begin{array}{l}75 \%-<90 \% \\
\text { (Baik) }\end{array}$ & 3 & 0,5 \\
\hline & $\begin{array}{l}90 \%-<105 \% \\
\text { (Lebih Baik) }\end{array}$ & 4 & 0,7 \\
\hline & $\begin{array}{l}105 \%-<120 \% \\
\text { (Sangat Baik) }\end{array}$ & 5 & 0,8 \\
\hline & $\begin{array}{l}\geq 120 \% \\
\text { (Istimewa) }\end{array}$ & 6 & 1 \\
\hline
\end{tabular}

Sumber : Data olahan (2015)

\section{c. Perilaku}

Indikator yang digunakan dalam menentukan promosi kenaikan jabatan berdasarkan perilaku yang terdiri dari :

1) Integritas Integritas yaitu berhubungan dengan kejujuran, dapat dipercaya dan senantiasa memegang teguh etika profesi dan bisnis.

2) Profesionalisme

Profesional adalah seorang karyawan bekerja secara optimal atas dasar kompetensi terbaik dengan penuh tanggung jawab.

3) Kerjasama

Cara bekerjasama dan saling mendukung dan bersinergi dalam mencapai target/ tujuan perusahaan antar sesama rekan kerja yang lain.

4) Kreatif

Kreatif adalah selalu berusaha mencari cara-cara baru untuk memberikan solusi terbaik.

5) Mengutamakan Pelayanan Kepada Pelanggan (Kepuasan Pelanggan)

Kepuasan pelanggan yaitu tanggap terhadap kebutuhan pelanggan dengan senantiasa menjadikan pelanggan sebagai mitra utama yang saling menguntungkan.

6) Berorientasi Pada Tujuan

Cara karyawan untuk selalu bekerja secara efektif, efisien dan tuntas untuk memberikan hasil yang optimal dalam mendukung pencapaian target perusahaan.

Tabel 3. Penilaian Perilaku

\begin{tabular}{|c|c|c|c|}
\hline Kriteria & Range & $\begin{array}{l}\text { Skala } \\
\text { Nilai }\end{array}$ & Bobot \\
\hline \multirow[t]{6}{*}{$\begin{array}{l}\text { Penilai- } \\
\text { an } \\
\text { Perilaku }\end{array}$} & $\begin{array}{l}\text { Perilaku yang } \\
\text { ditunjukkan } \\
<40 \% \quad \text { (Tidak } \\
\text { Baik) }\end{array}$ & 1 & 0,2 \\
\hline & $\begin{array}{lr}\text { Perilaku } & \text { yang } \\
\text { ditunjukkan } & 40 \% \\
-\quad<60 \% & \text { (Perlu } \\
\text { Perbaikan) } & \\
\end{array}$ & 2 & 0,3 \\
\hline & $\begin{array}{l}\text { Perilaku yang } \\
\text { ditunjukkan } 60 \% \\
-<80 \% \text { (Baik) }\end{array}$ & 3 & 0,5 \\
\hline & $\begin{array}{lr}\text { Perilaku } & \text { yang } \\
\text { ditunjukkan } & 80 \% \\
-<100 \% & \text { (Lebih } \\
\text { Baik) }\end{array}$ & 4 & 0,7 \\
\hline & $\begin{array}{l}\text { Perilaku yang } \\
\text { ditunjukkan } 80 \% \\
-\quad \leq 100 \% \text { dan } \\
\text { menjadi panutan } \\
\text { (Sangat Baik) }\end{array}$ & 5 & 0,8 \\
\hline & $\begin{array}{lr}\text { Perilaku yang } \\
\text { ditunjukkan } & 80 \% \\
-\quad \leq 100 \% & \text { dan } \\
\text { panutan serta } \\
\text { agen perubahan } \\
\text { (Istimewa) }\end{array}$ & 6 & 1 \\
\hline
\end{tabular}

Sumber : Data olahan (2015)

Ditentukan berdasarkan persyaratan utama atau kriteria-kriteria diatas, selanjutnya bobot preferensi (W)sebagai berikut:

$\mathrm{W} 1=$ Masa Kerja $(25 \%)=0,25$

$\mathrm{W} 2=$ Penilaian Kinerja $(50 \%)=0,50$

W3 $=$ Penilaian Perilaku $(25 \%)=0,25$

Dalam penentuan promosi kenaikan jabatan dengan metode Simple Additive Weight (SAW) berdasarkan kriteria-kriteria diatas maka diperoleh data sebagai berikut:

Tabel 4. Nilai dari masing-masing kriteria

\begin{tabular}{ccccc}
\hline \multirow{2}{*}{ No } & Nama & $\begin{array}{c}\text { Masa } \\
\text { Kerja }\end{array}$ & $\begin{array}{c}\text { Penilaian } \\
\text { Kinerja }\end{array}$ & Perilaku \\
\cline { 2 - 5 } 1 & $\begin{array}{l}\text { Chairani } \\
\text { Syifa }\end{array}$ & 4 Tahun & 5,30 & 4,92 \\
\hline 2 & $\begin{array}{l}\text { Rafida } \\
\text { Raudina }\end{array}$ & 3 tahun & 4,80 & 5,00 \\
\hline 3 & $\begin{array}{l}\text { Teguh } \\
\text { Purnomo }\end{array}$ & 2 Tahun & 4,90 & 4,83 \\
\hline 4 & $\begin{array}{l}\text { Wahyu } \\
\text { Guntoro }\end{array}$ & 2 Tahun & 5,07 & 4,83 \\
\hline 5 & $\begin{array}{l}\text { Siska } \\
\text { Febrina }\end{array}$ & 2 Tahun & 4,68 & 4,83 \\
\hline
\end{tabular}

Sumber : Data olahan (2015) 


\section{Penentuan Rating Kecocokan Setiap Alternatif Dengan Setiap Kriteria}

Dalam penentuan rating kecocokan maka nilai dari masing-masing kriteria dimasukkan kedalam tabel rating kecocokan yang telah disesuaikan dengan nilai dari tabel kriteria. Maka tabel rating kecocokan dapat dilihat sebagai berikut:

Tabel 5. Rating Kecocokan

\begin{tabular}{clccc}
\hline \multirow{2}{*}{ No } & Nama & \multicolumn{3}{c}{ Kriteria } \\
\cline { 3 - 5 } & $\begin{array}{c}\text { Masa } \\
\text { Kerja }\end{array}$ & $\begin{array}{c}\text { Penilaian } \\
\text { Kinerja }\end{array}$ & Perilaku \\
\hline 1 & $\begin{array}{l}\text { Chairani } \\
\text { Syifa }\end{array}$ & 0,6 & 0,8 & 0,8 \\
\hline 2 & $\begin{array}{l}\text { Rafida } \\
\text { Raudina }\end{array}$ & 0,4 & 0,8 & 0,8 \\
\hline 3 & $\begin{array}{l}\text { Teguh } \\
\text { Purnomo }\end{array}$ & 0,2 & 0,8 & 0,8 \\
\hline 4 & $\begin{array}{l}\text { Wahyu } \\
\text { Guntoro }\end{array}$ & 0,2 & 0,8 & 0,8 \\
\hline 5 & $\begin{array}{l}\text { Siska } \\
\text { Febrina }\end{array}$ & 0,2 & 0,8 & 0,8 \\
\hline
\end{tabular}

Sumber : Data olahan (2015)

\section{Membuat Matriks}

Berdasarkan Kriteria (Ci)

Nilai dari hasil tabel kecocokan kemudian dibuat kedalam bentuk matriks sebagai berikut:

$$
X\left[\begin{array}{ccc}
0,6 & 0,8 & 0,8 \\
0,4 & 0,8 & 0,8 \\
0,2 & 0,8 & 0,8 \\
0,2 & 0,8 & 0,8 \\
0,2 & 0,8 & 0,8
\end{array}\right]
$$

\section{Normalisasi Matriks}

Membuat Normalisasi Matriks berdasarkan persamaan yang disesuaikan dengan jenis atribut (atribut keuntungan maupun atribut biaya) sehingga diperoleh matriks ternormalisasi R.

Tabel 6. Penentuan Benefit atau Cost

\begin{tabular}{lcl} 
Kriteria & Benefit & Cost \\
\hline Masa Kerja & V & - \\
\hline Penilaian Kinerja & V & - \\
\hline Perilaku & V & - \\
\hline Sumber : Data olahan (2015)
\end{tabular}

Menentukan nilai $\mathrm{R}$ dengan rumus sebagai berikut:

$R_{i j}=\frac{X_{i j}}{\operatorname{Max} X_{i j}}$

\section{a. Untuk Kriteria Masa Kerja}

$R_{11}=\frac{0,6}{\operatorname{Max}(0,6,0,4,0,2,0,2,0,2)}$

$R_{11}=\frac{0,6}{0,6}=1$

$R_{21}=\frac{0,4}{\operatorname{Max}(0,6,0,4,0,2,0,2,0,2)}$

$R_{21}=\frac{0,4}{0,6}=0,6667$

$R_{31}, R_{41}, R_{51}=\frac{0,2}{\operatorname{Max}(0,6,0,4,0,2,0,2,0,2)}$

$R_{31}, R_{41}, R_{51}=\frac{0,2}{0,6}=0,3333$

Maka untuk $\mathrm{R}_{11}$ memiliki nilai $1, \mathrm{R}_{21}$ memiliki nilai 0,6667 kemudian untuk $R_{31}, R_{41}$, dan $R_{51}$ memiliki nilai yang sama yaitu 0,3333 .

\section{b. Untuk Kriteria Penilaian Kinerja}

$R_{12}=\frac{0,8}{\operatorname{Max}(0,8,0,8,0,8,0,8,0,8)}$

$R_{12}=\frac{0,8}{0,8}=1$

Maka $\mathrm{R}_{12}, \mathrm{R}_{22}, \mathrm{R}_{32}, \mathrm{R}_{42}$, dan $\mathrm{R}_{52}$ memiliki nilai $\mathrm{R}$ yang sama sebab semua angka pada kolom tersebut memiliki nilai yang sama.

Jadi, $\mathrm{R}_{12}=\mathrm{R}_{22}=\mathrm{R}_{32}=\mathrm{R}_{42}=\mathrm{R}_{52}=1$

\section{c. Untuk Kriteria Perilaku}

$R_{13}=\frac{0,8}{\operatorname{Max}(0,8,0,8,0,8,0,8,0,8)}$

$R_{13}=\frac{0,8}{0,8}=1$

Maka $\mathrm{R}_{13}, \mathrm{R}_{23}, \mathrm{R}_{33}, \mathrm{R}_{43}$, dan $\mathrm{R}_{53}$ memiliki nilai $\mathrm{R}$ yang sama sebab semua angka pada kolom tersebut memiliki nilai yang sama.

Jadi, $\mathrm{R}_{13}=\mathrm{R}_{23}=\mathrm{R}_{33}=\mathrm{R}_{43}=\mathrm{R}_{53}=1$

Dari perhitungan diatas diperoleh matriks $\mathrm{R}$ sebagai berikut:

$$
R\left[\begin{array}{ccc}
1 & 1 & 1 \\
0,6667 & 1 & 1 \\
0,3333 & 1 & 1 \\
0,3333 & 1 & 1 \\
0,3333 & 1 & 1
\end{array}\right]
$$




\section{Menentukan Rangking}

Untuk mencari nilai dari masing-masing karyawan yang akan mendapat promosi jabatan, berikut proses menentukan rangking:

Menentukan nilai $\mathrm{V}_{1}$ sampai dengan $\mathrm{V}_{4}$ adalah sebagai berikut:

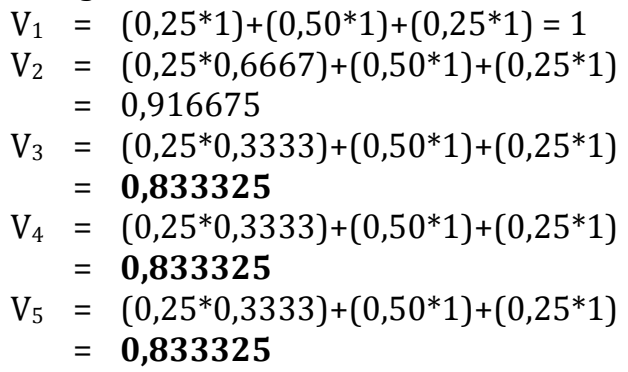

Dari hasil perhitungan nilai $\mathrm{V}_{\mathrm{i}}$ dari setiap karyawan yang akan mendapatkan promosi kenaikan jabatan maka dapat dibuatkan tabel penentuan rangking sebagai berikut:

Tabel 7. Penentuan Rangking

\begin{tabular}{lllcc}
\hline No & Nama & Nilai & $\begin{array}{c}\text { Persentase } \\
(\%)\end{array}$ & Rangking \\
\hline 1 & $\begin{array}{l}\text { Chairani } \\
\text { Syifa }\end{array}$ & 1 & $100 \%$ & 1 \\
\hline 2 & $\begin{array}{l}\text { Rafida } \\
\text { Raudina }\end{array}$ & 0,916675 & $92 \%$ & 2 \\
\hline 3 & $\begin{array}{l}\text { Teguh } \\
\text { Purnomo }\end{array}$ & 0,833325 & $83 \%$ & 3 \\
\hline 4 & $\begin{array}{l}\text { Wahyu } \\
\text { Guntoro }\end{array}$ & 0,833325 & $83 \%$ & 4 \\
\hline 5 & $\begin{array}{l}\text { Siska } \\
\text { Febrina }\end{array}$ & 0,833325 & $83 \%$ & 5 \\
\hline
\end{tabular}

Sumber : Data olahan (2015)

Dari penentuan prioritas usulan promosi kenaikan jabatan dengan menggunakan metode Simple Additive Weight maka yang layak mendapatkan promosi kenaikan jabatan adalah karyawan bernama Chairani Syifa yang memiliki nilai 1.

\section{Desain Sistem}

Berikut desain sistem pendukung keputusan promosi kenaikan jabatan.

a. Perancangan Use Case Diagram SDM
Sumber : Data olahan (2015)

Gambar 2. Perancangan Use Case Diagram SDM

b. Perancangan Use Case Diagram Ruang Manager Bagian

Sumber : Data olahan (2015)

Gambar 3. Perancangan Use Case Diagram Ruang Manager Bagian

c. Perancangan Use Case Diagram Staff

Sumber : Data olahan (2015)

Gambar 3. Perancangan Use Case Diagram Ruang Karyawan

\section{Desain Database}

Berikut desain database dengan menggunakan Entity Relationship Diagram (ERD) 


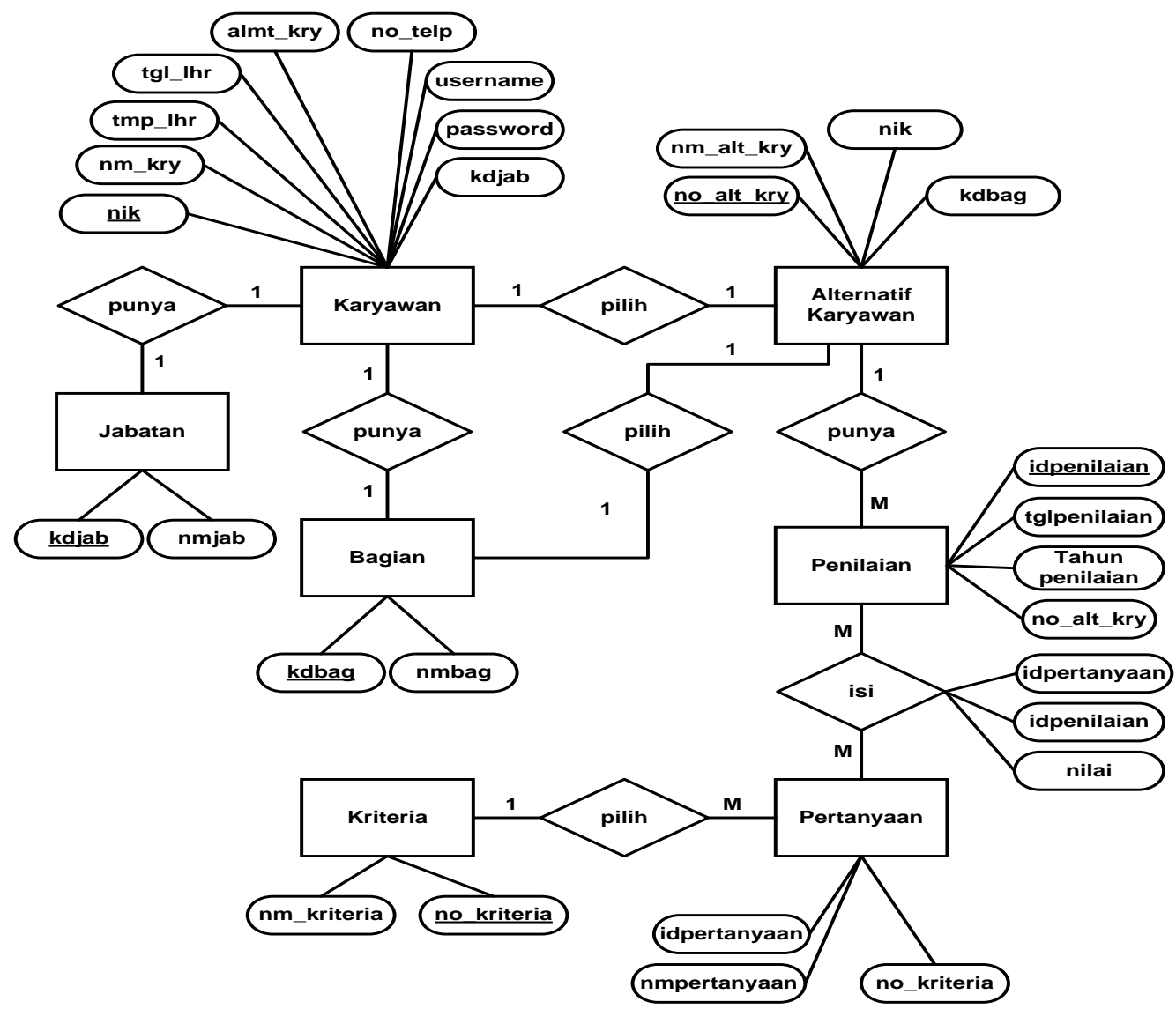

Sumber : Data olahan (2015)

Gambar 4. Perancangan Database

\section{Desain Rancangan Layar}

a. Rancangan Login

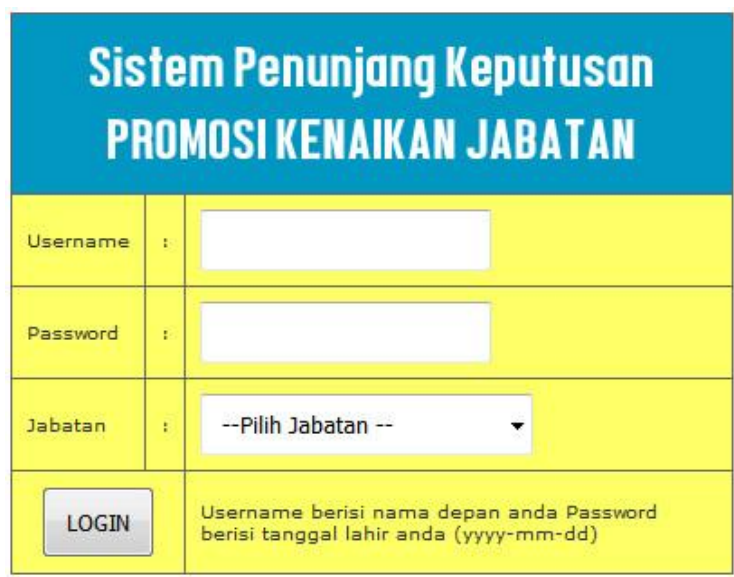

Sumber : Data olahan (2015)

Gambar 5. Login Form b. Rancangan Masukan Nilai Kriteria

\begin{tabular}{|l|l|l|l|}
\hline \multicolumn{3}{|c|}{ INPUT DATA PENILAIAN PROMOSI JABATAN } \\
\hline Tanggal Penilaian & $: 25$ Oct 2015 & Tahun : 2015 \\
\hline N.I.K. & $:$ & 201310312 & CARI \\
\hline
\end{tabular}

\begin{tabular}{|l|l|l|}
\hline Nama Karyawan & $:$ & Siska Febrina \\
\hline Jabatan & $:$ & Staff TI \\
\hline Bagian & $:$ & Teknologi Informasi \\
\hline Masukan Kriteria & $:$ & 2 \\
\hline Masa Kerja & $:$ & 4,68 \\
\hline Penilaian Kinerja & $:$ & 4,83 \\
\hline Perilaku & \multicolumn{2}{|l|}{ PROSES } \\
\hline
\end{tabular}

Sumber : Data olahan (2015)

Gambar 6. Rancangan Masukan Nilai Kriteria 
c. Rancangan Keluaran Nilai Akhir

\begin{tabular}{|c|c|c|c|c|c|r|}
\hline \multirow{2}{*}{ No } & \multirow{2}{*}{ NIK } & \multicolumn{3}{|c|}{ Kriteria } & \multirow{2}{*}{ Hasil } & $\begin{array}{c}\text { Persentase } \\
(\%)\end{array}$ \\
\cline { 3 - 5 } & & Masa Kerja & Penilaian Kinerja & Perilaku & & \\
\cline { 3 - 5 } & $25 \%$ & $50 \%$ & $25 \%$ & & 100 \\
\hline 1 & Chairani Syifa & $\mathbf{0 , 2 5}$ & $\mathbf{0 , 5}$ & $\mathbf{0 , 2 5}$ & 1 & 92 \\
\hline 2 & Rafida Raudina & 0,16667 & 0,5 & 0,25 & 0,9167 & 83 \\
\hline 3 & Teguh Purnomo & 0,08333 & 0,5 & 0,25 & 0,8333 & 83 \\
\hline 4 & Wahyu Guntoro & 0,08333 & 0,5 & 0,25 & 0,8333 & 83 \\
\hline 5 & Siska Febrina & 0,08333 & 0,5 & 0,25 & 0,8333 & 83 \\
\hline
\end{tabular}

Sumber : Data olahan (2015)

Gambar 7. Rancangan Keluaran Nilai Akhir

\section{KESIMPULAN}

Kesimpulan pembahasan penelitian adalah sebagai berikut:

1. Dari aspek manajerial penilaian dapat dikembangkan dengan kriteria-kriteria yang lain sesuai dengan kebutuhan perusahaan.

2. Dari perhitungan dengan menggunakan metode Simple Additive Weight, dengan acuan kriteria masa kerja, penilaian kinerja, dan penilaian perilaku karyawan, maka terpilih seorang karyawan yang akan mendapatkan promosi jabatan, yaitu karyawan bernama Chairani Syifa.

3. Dari Hasil Analisis perhitungan dengan menggunakan metode Simple Additive Weight dan dari hasil kuisioner penilaian karyawan yang terdiri dari kriteria masa kerja, penilaian kinerja, dan penilaian perilaku, karyawan bernama Chairani Syifa mendapatkan nilai sempurna dengan persentase $100 \%$. Dengan rincian penilaian masa kerja selama 4 tahun mendapatkan nilai bobot 0,6 , penilaian kinerja sebesar 5,30 mendapatkan bobot 0,8 , dan penilaian perilaku 4,92 mendapatkan nilai bobot 0,8.

4. Dengan demikian untuk mendapatkan promosi jabatan seorang karyawan tidak hanya dilihat dari segi seberapa lamanya karyawan tersebut bekerja tetapi juga harus memiliki kinerja dan perilaku yang baik.

\section{KESIMPULAN}

Kesimpulan pembahasan penelitian adalah sebagai berikut:

1. Dari aspek manajerial penilaian dapat dikembangkan dengan kriteria-kriteria yang lain sesuai dengan kebutuhan perusahaan.

2. Dari perhitungan dengan menggunakan metode Simple Additive Weight, dengan acuan kriteria masa kerja, penilaian kinerja, dan penilaian perilaku karyawan, maka terpilih seorang karyawan yang akan mendapatkan promosi jabatan, yaitu karyawan bernama Chairani Syifa.

3. Dari Hasil Analisis perhitungan dengan menggunakan metode Simple Additive Weight dan dari hasil kuisioner penilaian karyawan yang terdiri dari kriteria masa kerja, penilaian kinerja, dan penilaian perilaku, karyawan bernama Chairani Syifa mendapatkan nilai sempurna dengan persentase $100 \%$. Dengan rincian penilaian masa kerja selama 4 tahun mendapatkan nilai bobot 0,6 , penilaian kinerja sebesar 5,30 mendapatkan bobot 0,8 , dan penilaian perilaku 4,92 mendapatkan nilai bobot 0,8.

4. Dengan demikian untuk mendapatkan promosi jabatan seorang karyawan tidak hanya dilihat dari segi seberapa lamanya karyawan tersebut bekerja tetapi juga harus memiliki kinerja dan perilaku yang baik.

\section{REFERENSI}

Asnawati, Indra Kanedi. 2012. Sistem Pendukung Keputusan Kenaikan Pangkat Karyawan Perseroan Terbatas Pelayaran Kumafa Lagun Marina Bengkulu. ISSN: 1858-2680. Bengkulu: Jurnal Media Infotama Vol.8, No. 1 Februari 2012: 118-137

Badriyah, Mila. 2015. Manajemen Sumber Daya Manusia. Bandung: Pustaka Setia.

Hamidi. 2007. Metode Penelitian dan Teori Komunikasi. UMM Press: Malang.

Hartono, Bambang. 2013. Sistem Informasi Manajemen Berbasis Komputer. Jakarta: Rineka Cipta.

Kusrini. 2007. Konsep dan Aplikasi Sistem Pendukung Keputusan. Yogyakarta: Andy Offset.

Munthe, Hotmaria Ginting. 2013. Sistem Pendukung Keputusan Penentuan Prioritas Usulan Sertifikasi Guru Dengan Metode Simple Additive Weighting. ISSN: 2301-9425. Medan: Pelita Informatika Budi Darma Vol IV, No. 2 Agustus 2013: 52-58

Nofriansyah, Dicky. 2014. Konsep Data Mining VS Sistem Pendukung Keputusan. Yogyakarta: Deepublish.

Rinaldi, M. Arfan. 2013. Sistem Pendukung Keputusan Pemilihan Trainer (Staf Pengajar) Menggunakan Metode Metode Simple Additive Weighting (SAW) (Studi Kasus: Primagama English Johor). ISSN: 2301-9425. Medan: Pelita Informatika Budi Darma Vol V, No. 1 November 2013: 98-102

Silalahi, M. Sulaiman. Sistem Pendukung Keputusan Kenaikan Jabatan Dengan Menggunakan Metode Simple Additive Weighting (SAW) (Studi Kasus: Gapeksindo Medan). ISSN: 2301-9425. Medan: Pelita 
Informatika Budi Darma Vol V, No. 1 November 2013: 15-20

Sugiyono. 2009. Metode Penelitian Kuantitatif dan Kualitatif dan R\&D. Bandung: Alfabeta

\section{BIODATA PENULIS}

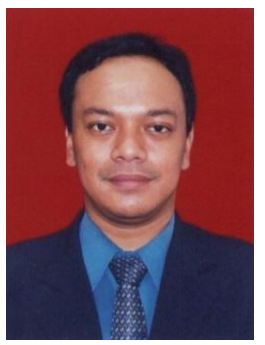

Frieyadie, M.Kom. Jakarta 5 Juli 1974. Lulusan DIII-MI Universitas. Gunadarma tahun 1996, Lulusan S1 Jurusan Manajemen Informatika STMIK Jayakarta, Lulusan Pascasarjana Ilmu Komputer STMIK Nusa Mandiri. Pernah bekerja di Sempati Air, sebagai Verifikasi Data Entri, Dosen BSI dan Nusa Mandiri. Pernah melakukan penelitian diantaranya Perancangan Sistem Informasi Customer Complaint Pada PT. Astra Internatioinal Daihatsu Berbasis Web Dengan Menggunakan Model Rapid Application Development (2013). Penerapan Rapid Application Development Model Pada Perancangan dan Kajian Sistem Informasi Penjalan Berbasis Web (2015). 